\title{
Circuit
}

Musiques contemporaines

\section{Mesostic for Mario}

\section{Andrew Culver}

Volume 15, numéro 1, 2004

Interpréter la musique (d')aujourd'hui

URI : https://id.erudit.org/iderudit/902346ar

DOI : https://doi.org/10.7202/902346ar

Aller au sommaire du numéro

Éditeur(s)

Les Presses de l'Université de Montréal

ISSN

1183-1693 (imprimé)

1488-9692 (numérique)

Découvrir la revue

Citer ce document

Culver, A. (2004). Mesostic for Mario. Circuit, 15(1), 96-100.

https://doi.org/10.7202/902346ar

Ce document est protégé par la loi sur le droit d'auteur. L'utilisation des services d'Érudit (y compris la reproduction) est assujettie à sa politique d'utilisation que vous pouvez consulter en ligne.

https://apropos.erudit.org/fr/usagers/politique-dutilisation/
Cet article est diffusé et préservé par Érudit.

Érudit est un consortium interuniversitaire sans but lucratif composé de l'Université de Montréal, l'Université Laval et l'Université du Québec à Montréal. Il a pour mission la promotion et la valorisation de la recherche. https://www.erudit.org/fr/ 


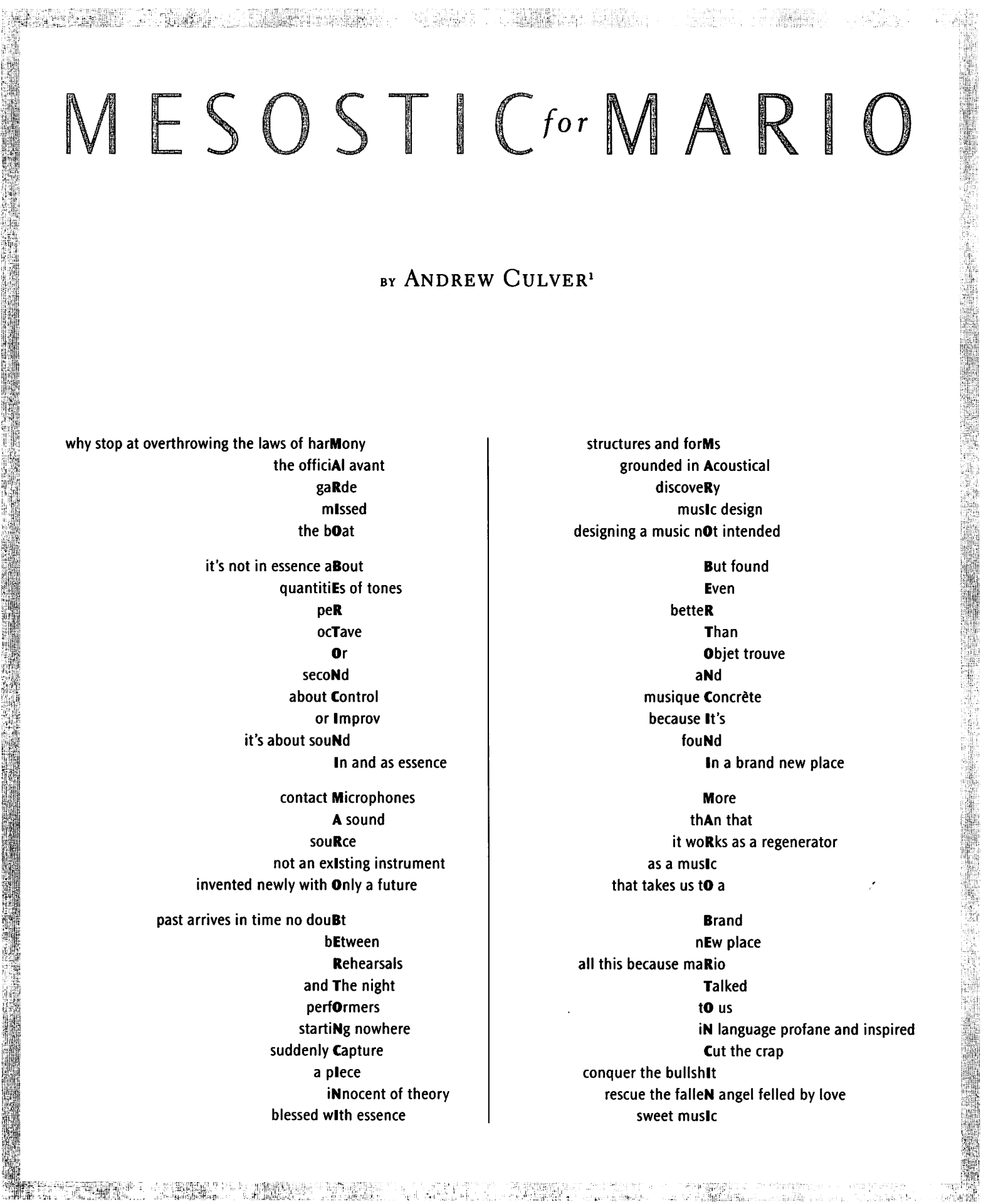




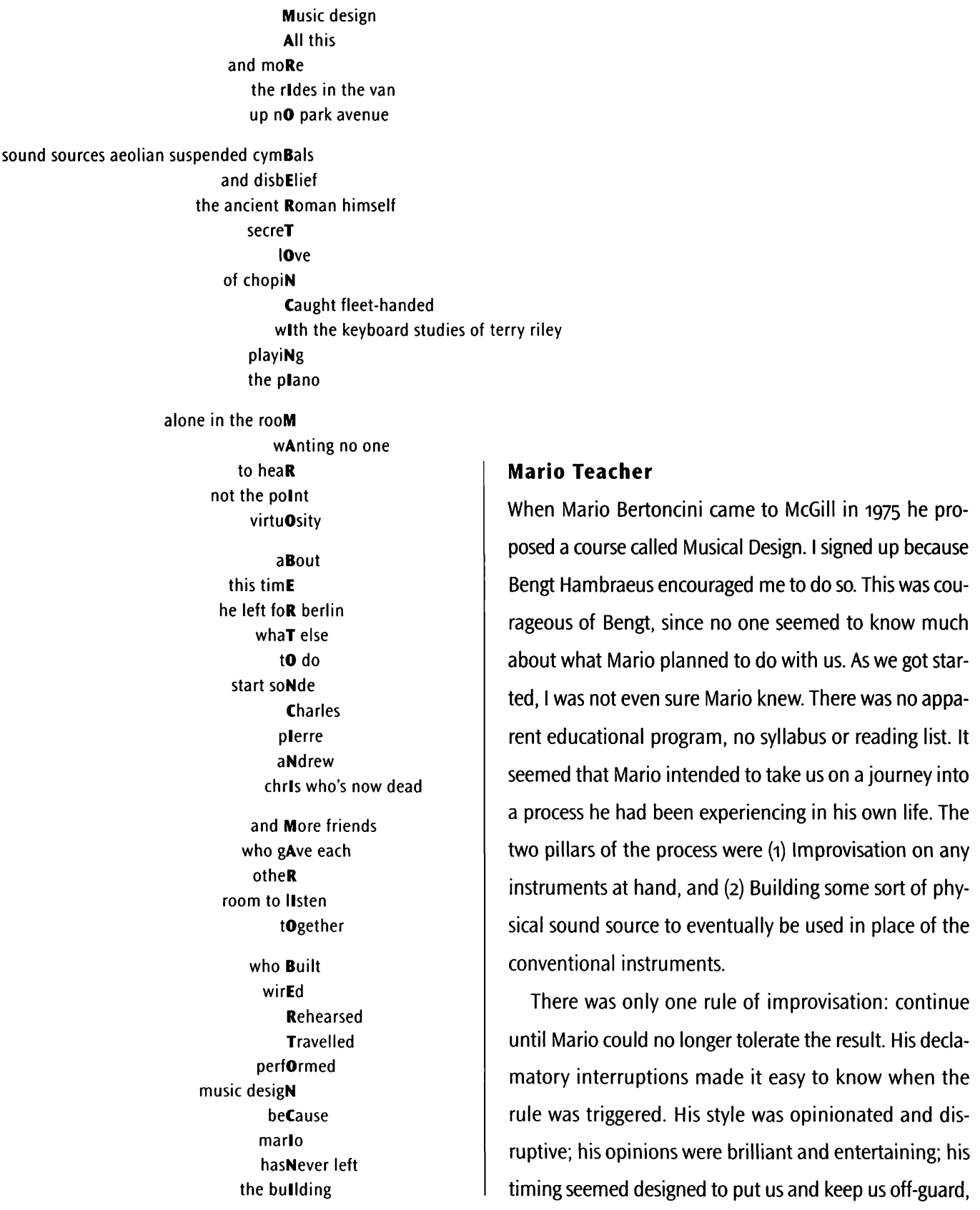


dependent on intuition over logic; he seemed to hope to induce in us more a sense of balance than any accessible knowledge. He taught us improvisation the way a kid might teach an irritatingly clueless but nonetheless lovable younger cousin how to ride a two-wheeler bicycle: basically, by pushing us forward and picking us up when we fell. He talked or listened, we played; doing preempted discussing.

The sound source designing and building had, relative to the improvisation teaching, a more discernable objective: make something that could eventually be used to play a piece of music. Without ever taking on the weight of theory, one strong principle emerged: the things we built could not be separated from the pieces we would play with them. As we realized this, I came to see that the words "instrument" and "composition" were insufficient. The process embraced a broader exploration. Broader, and more integrated than expected. The improvisational training, it turned out, was not a separate exercise; nor was it a performance technique, a compositional resource, or a form or style. It was an essential tool in the overall project, essential to realizing the potential of the newly built sound sources. How else to know the unknown than by sailing through it as ideas crash on the rocks? How else to meet new adventures than by building an unknown sea?

So Mario's plan turned out to be surprisingly simple and ambitious: to teach invention of new musics.

\section{Music Design}

I have made various attempts at a formal definition of music design over the years. (I used to use "musical design" but now prefer "music design".) A typical rendition is this one from 1984 :

The exploration into the sonic possibilities of various materials in various formats, the design and construction of sound sources based on these findings and suitable for performance, and the re-exploration into the sonic worlds of the sound sources during performance through exquisite improvisation (from seeking, not providing) is a compositional process called musical design.

Here's something from 1988:

The music designer researches the sonic natures of various materials in various formats, designs and constructs sound sources suitable for performances and/or installation, and develops activity interfaces that allow the energies of the players to inform the sound sources.

Typically, I wrote these definitions to introduce audiences and critics to a way of making music that was little known. (The situation is still true, and regrettable, and not only because of the musical opportunities lost for listeners.) Looking back, I now find them too linear and narrow. They imply that invention of new devices is essential to the process. Indeed that is what audiences often find most memorable. But music is made three ways these days: on paper, in the studio, and through invention and construction. To me there are important concepts within music design that apply to all three, transcending the one that features construction. A new definition of music design should embrace all three.

Music design is a comprehensive activity of individual or collective experimentation, invention, composition, performance, installation and recording that continuously seeks a renewal of the musical creative process. The comprehensive capabilities of the music designer actively examine all 
aspects of music making, questioning all forms, theories, and tools, consciously accepting and using, or rejecting and designing around, all musical practices and technologies.

This definition says more about the process and less about the result. It is aesthetically independent. It does not discredit the acceptance and use of existing practices and technologies, so long as they are critically and consciously pre-examined. It encompasses partial processes that do not re-invent the entire sequence of music making - such as the composition of a string quartet, or the building of a sound sculpture, or the recording of a CD by a band of musicians - provided the accepted components are accepted under advisement.

When, by desire, or by critical rejection of an existing component of the music making process, something new is required, active design kicks in. The critical pre-examination of existing tools and practices can be referred to as passive design. Design is always present, like an additional, permanent dimension added to all the other musical dimensions.

Though it may not need saying, music too is always present. This is not a research project. Products and theories are not the goal. Music design is not thinking about music, it is making music.

\section{Then Now Next}

Demanding active doubt with respect to accepted norms, music design is an ideal way to counter the ignorance of bandwagons. Back in 1975, at least in Mario's sparkling eyes, the bandwagon was "the current official Avant-garde" ${ }^{3}$, responsible for countless self-congratulatory rules and imitative gestures that presupposed everything except the existence of beauty beyond its borders. As SONDE was once asked on its sole descent into IRCAM (in 1984), did we really expect Boulez or Stockhausen to write for our sound sources?

Over the years, music design has held up nicely as a buttressing process against a succession of crushing norms. The current boogieman is technology itself.

Marshall McLuhan suggested four decades ago that technology was replacing art as revealer of the human experience. Last year's top music story is not a tune, it was iTunes. The current authors of the musical hottopics are not composers; they are entrepreneurs and digital technologists, specialists joined together in enterprises trying to reach consumers. There is really no place for musicians and composers in those enterprises: they are convoluted and indirect, while the strength of an artist is simple and direct. Even so, many composers are drawn to having a prominent place at technology's party, seeking access to the empowering cachet of technical complexity, devoting time and ambition to riding the bandwagon. Career opportunities aside, it's a bad idea. Technology, even only music technology, is too big to comprehend individually. Technology is not so much an activity you can do as a field that surrounds you; not who you are, just where you are.

Music design offers the best process for compositional/technological synergy. The balance is correct, the path always individually accessible, the objective always within individual reach. No matter what specific technologies are employed or devised, or what aesthetic temperament prevails, music design insists first and foremost that performance, creation and invention play 
together without interruption or master. Music design is how to engage technology without loss of music.

As to the future, as John Cage aptly stated, "we won't know till we get there". But given all the walls that have fallen in the past quarter century, all the styles, theories and means that no longer seem in opposition to one another, when even technology - perhaps the final obstacle - turns out to be as thin as rice paper, useable but not obstructing, we find ourselves once again in a brand new place. I see it as a very open, unthreatening and boundless space - like outer space, but not so cold, and with air for sound and breathing. What processes will emerge that assist musicians in the making of music in such an unfettered space? Well, think about what's needed: the ability to use what works, ferret out what restricts, invent what's missing, construct the new, reach for the reachable, enjoy each other, and play. Music design.

\section{ENDNOTES}

1. The poem that accompanies this article pays homage to two of my key mentors: Mario Bertoncini and John Cage. Its content is thanks to one, its form, thanks to the other.

A mesostic is a poetic form devised by John Cage. It consists of a string of letters aligned vertically down the center of the page, and words around these letters that read normally across the page. The string down the middle is called the meso string. Meso string letters are called meso letters. Meso letters are always capitalized. The word across the page in which a meso letter appears is called a meso word. Additional words to the left or right of a meso word are called wing words.

The meso string spells out a word or phrase in its own right. This is often a person's name because Cage started writing mesostics as a response to requests that he write something about someone he knew, often to mark a birthday or other important date. However any phrase will do and Cage often wrote extended dissertations on subjects important to him using the mesostic form, with meso strings that encapsulate ideas or consist of keywords related to the subject.

An important and sometimes overlooked aspect of mesostics is that there are rules restricting the use of meso letters. The $50 \%$ rule states that a meso letter must not appear between itself and the previous meso letter. So, for example, if the meso string is "MARIO", then between the M and the A there must not be any a's, and between the $A$ and the $R$ there must not be any r's, and so on. The $100 \%$ rule states that a meso letter must not appear between the previous meso letter and the next meso letter, other than its own occurrence. Based on "MARIO", the letter a must not appear anywhere between the $M$ and the $R$, except the one time the meso letter $A$ appears itself. Proofreading a long or even a short mesostic can prove fiendishly error-prone, which is why I wrote mesoproofing software at Cage's request. Anyone can write a mesostic: just decide on a meso string, and choose the $50 \%$ or $100 \%$ rule. And watch out for mistakes!

2. Dissatisfied with watered down uses of the word "improvisation", often meaning no more than extemporization on a rigid rhythmic, melodic and harmonic framework, I came up with the phrase "exquisite improvisation" to describe what we were engaged in. Etymologically, improvisation attaches a negative prefix to "provision", and exquisite implies a result caused by seeking. From seeking not providing. Exquisite improvisation downplays conventions and emphasizes exploration.

3. Mario Bertoncini, from a letter to the MuD Group. (See the complete letter reproduced, in the article by Charles de Mestral, p. 93). 